\section{La santé publique et le triste héritage des pensionnats indiens}

Au tout début de l'été, la Commission de vérité et réconciliation du Canada tenait son événement de clôture à Ottawa, " dans le but de promouvoir la sensibilisation et l'éducation du public à l'égard du système des pensionnats indiens et de ses séquelles »1. Cet événement fut marqué notamment par la publication des conclusions de la Commission ${ }^{2}$. Il s'agit sans aucun doute d'un document extrêmement important pour la santé publique canadienne, je dirais même une lecture obligatoire pour tous ceux qui s'intéressent à la santé des populations.

Ce rapport est l'aboutissement d'une enquête qui a amené les commissaires à dépouiller des milliers de documents, à entendre des centaines de témoignages et à participer à des dizaines d'événements publics dits de réconciliation. Bien qu'il n'ait pas été écrit dans un objectif de santé publique, ce document constitue un témoignage éloquent de l'impact durable, populationnel et intergénérationnel de ce qu'il est maintenant convenu d'appeler les déterminants sociaux de la santé. La principale conclusion de la Commission, celle qui fut largement médiatisée, est que le système fédéral des pensionnats indiens, en place de 1867 à 1998, était un instrument privilégié du génocide culturel auquel s'est livré le gouvernement de notre pays envers les peuples autochtones, à partir de sa création et jusqu'à tout récemment. Les mots sont très durs et peuvent même faire peur, mais au fil des pages du rapport, on conçoit que les conditions de vie des enfants (car c'est bien d'enfants qu'il s'agissait, même si ceux-ci sont maintenant des adultes) qui ont subi un tel régime sont intolérables dans une nation dite "civilisée ». Ce qui est décrit avec force détails et témoignages de survivants dans la première section du rapport, c'est un effort structurel, systématique pour " tuer l'Indien dans l'Indien ». Les victimes immédiates d'un tel système furent certes les enfants, mais la Commission met aussi en lumière comment, à travers eux, leurs parents et aussi leurs enfants et leurs communautés ont été, et sont encore, touchés dans toutes les sphères de leur vie. Ceci est sans conteste un élément critique qui conditionne le contexte de la pratique de la santé publique au Canada.

Cette première section constitue aussi un exemple probant de l'imbrication de l'ensemble des déterminants de la santé. On y constate clairement que la mise en œuvre des violences symboliques telles que l'interdiction des langues et des habits traditionnels, nécessaires pour assurer l'annihilation des cultures autochtones, s'accompagne nécessairement de violences physiques qui laissent des traces dans les corps. Le délabrement et la vétusté des bâtiments, l'absence de ressources et de formation des personnels, la malnutrition et les déficiences d'hygiène, la mise au travail des enfants, les châtiments corporels et les abus sexuels qui sont documentés dans le rapport ne sont pas des accidents de parcours. Ils sont la conséquence inéluctable de l'extrême violence de l'objectif poursuivi. Même si un très grand nombre de dossiers des enfants de ces pensionnats furent détruits, la Commission qui a tenté de constituer des registres estime que la mortalité des enfants âgés entre 5 et 15 était cinq

\section{Public health and the sad legacy of Indian residential schools}

Early this summer, Canada's Truth and Reconciliation Commission held its closing event in Ottawa "with the goal of promoting awareness and public education about the Indian residential school system and its legacy". "This event was marked, in particular, by the publication of the Commission's conclusions. $^{2}$ It is undoubtedly an extremely important document for Canadian public health; I would even say required reading for all those who are interested in population health.

This report is the culmination of an investigation that led the Commissioners to uncover thousands of documents, listen to hundreds of testimonies and participate in dozens of public reconciliation events. This report, while not written with a public health goal, constitutes eloquent testimony as to the enduring, population and intergenerational impact of what has now come to be known as the social determinants of health. The principal conclusion of the Commission, the one that has been most publicized, is that the Federal Indian Residential School System, in place from 1867 to 1998, was a preferred instrument of cultural genocide used by our country's government against Aboriginal people, from the time it was created until very recently.

The words are harsh and could even inspire fear. But, through the pages of the report we comprehend that the living conditions of the children who were subjected to such a system (because we really are talking about children here, even if they are now adults) were intolerable in a so-called "civilized" nation. What is described in the first section of the report, in considerable detail and through the testimony of survivors, is a structured, systematic effort to "kill the Indian in the Indian". The immediate victims of such a system were, unquestionably, the children; but the Commission also shed light on how the victims' parents, children and communities were, and still are, affected in all aspects of their lives. This is without question a critical element that influences the context of public health practice in Canada.

This first section also constitutes a striking example of the interlinking of the full range of health determinants. In it we can clearly see that the implementation of symbolic violence, such as the prohibition of languages and traditional customs, necessary to assure the annihilation of Aboriginal cultures, is necessarily accompanied by physical violence that leaves traces in bodies. The disrepair and obsolescence of buildings, the absence of resources and training of personnel, malnutrition and inadequate sanitation, use of child labour, corporal punishment and sexual abuse, all documented in the report, are not mere bumps in the road. They are the inevitable consequences of the extreme violence of the goal being pursued.

Even though a great number of the files for the children and the residences have been destroyed, the Commission that tried to establish records estimates that the mortality rate for children between 5 and 15 years of age was five times higher in the Indian residential schools than in the general population of the 
fois plus élevée dans les pensionnats indiens que dans la population générale du même âge. Lorsqu'enregistrées, les principales causes de décès étaient : la tuberculose, l'influenza, la pneumonie et autres maladies respiratoires - des affections dont les causes premières sont la malnutrition, l'insalubrité et une ventilation déficiente; autrement dit, la misère.

La seconde section du rapport examine l'héritage d'un tel système qui, bien qu'il soit maintenant complètement démantelé, a laissé des traces durables dans tous les aspects de la vie des communautés autochtones au pays. Cette liste, longue et inclusive, fait toutefois une large place à l'action. La Commission établit des liens convaincants entre plus de cent ans d'un génocide culturel et les situations de déficit dans lesquelles se retrouvent actuellement les communautés autochtones dans les sphères suivantes : le bien-être des enfants, l'éducation, la langue et la culture, la santé et la justice. Pour corriger cet héritage, la Commission formule 42 appels à l'action dont 7 concernent plus directement la santé (voir l'encadré). Il me semble que les acteurs de santé publique doivent leur porter une attention particulière et développer des plans d'action en conséquence. Il faut aussi garder en tête que dans leur ensemble, les recommandations de la Commission interpellent la plupart des institutions publiques canadiennes et constituent un large menu intersectoriel dans lequel la santé publique, comme institution qui a aussi sa part de responsabilité dans les conséquences néfastes du système des pensionnats, pourrait exercer son leadership.

Enfin, à travers 52 autres appels à l'action, c'est la société canadienne toute entière que la Commission invite à la réconciliation. Elle nous invite à créer les conditions et institutions qui assurent non seulement notre devoir collectif de mémoire concernant les événements passés mais aussi le respect mutuel des peuples qui composent notre pays. Parce que la question de l'équité en matière de santé pour les populations autochtones est un des enjeux clé de cette démarche, il est important que la santé publique canadienne se mobilise, confronte cet héritage collectif et se mette au boulot pour élaborer les conditions d'une réconciliation dans le respect mutuel.

C'est dans cet esprit de respect mutuel et de réconciliation que la Revue canadienne de santé publique a ouvert sa page éditoriale à $\mathrm{D}^{\text {re }}$ Janet Smylie. Métis et titulaire d'une Chaire de recherche appliquée en santé des populations, $\mathrm{D}^{\text {re }}$ Smylie est incontestablement une des leaders de la recherche en santé des populations autochtones au Canada, une recherche qui, comme le savent ceux qui l'ont pratiquée, doit aussi s'inscrire dans un processus de réconciliation et mettre en œuvre des pratiques qui assurent le respect et l'autonomie des individus et des communautés.

Louise Potvin, Ph.D.

Rédactrice en chef, RCSP

Université de Montréal

doi : $10.17269 / \mathrm{CJPH} .106 .5264$ same age. Where registered, the main causes of death were: tuberculosis, influenza, pneumonia and other respiratory illnesses - diseases for which the primary causes are malnutrition, squalor and inadequate ventilation; in other words, destitution.

The second section of the report examines the legacy of this sort of system that, although it is now completely dismantled, has left enduring traces in all aspects of Aboriginal community life, throughout the country. However, this long and inclusive list leaves ample room for action. The Commission established convincing ties between the more than 100 years of cultural genocide and the shortfall situations that Aboriginal communities currently find themselves in... areas such as: children's well-being, education, language and culture, health and justice. To correct this legacy, the Commission drew up 42 calls to action, of which 7 most directly affect health (see textbox). It seems to me that public health practitioners and decision makers must pay particular attention to them and develop appropriate action plans. Also keep in mind that, taken as a whole, the Commission's recommendations challenge the majority of Canadian public institutions representing a broad cross-sectoral menu within which public health, as an institution that also has its share of responsibility in the adverse consequences of the residential system, could exercise its leadership.

Finally, through 52 other calls to action, the Commission invites the entire Canadian society to reconciliation. It invites us to create conditions and institutions that ensure not only our collective duty to remember past events but also the mutual respect of the people who make up our country. Because equity in health for Aboriginal populations is one of the key issues in this process, it is important that Canadian public health rallies, confronts this collective legacy and puts a shoulder to the wheel to develop the conditions for reconciliation, in mutual respect.

It is in this spirit of mutual respect and reconciliation that the Canadian Journal of Public Health has opened its editorial page to Dr. Janet Smylie. As a Métis and the holder of a Chair in Applied Public Health Research, Dr. Smylie is unquestionably one of the leaders in Aboriginal population health in Canada. Such research, as those who practise it know, must also be incorporated into the reconciliation process and must implement practices that ensure the respect and autonomy of individuals and communities.

Louise Potvin, PhD

Editor in Chief, CJPH

Université de Montréal

doi: $10.17269 / \mathrm{C} \mid \mathrm{PH} .106 .5264$ 


\section{RÉFÉRENCES BIBLIOGRAPHIQUES}

1. Sur Internet : http://www.trc.ca/websites/trcinstitution/index.php?p=831

2. Commission de vérité et réconciliation du Canada. Honoring the truth, reconciling the future: Summary of the final report of the Truth and Reconciliation Commission of Canada. 2015. Sur Internet : http://www.trc.ca/ websites/trcinstitution/File/2015/Honouring_the_Truth_Reconciling_for_ the_Future_July_23_2015.pdf

Appels à l'action concernant la santé de la Commission de vérité et réconciliation du Canada

1. Nous demandons au gouvernement fédéral, aux gouvernements provinciaux et territoriaux ainsi qu'aux gouvernements autochtones de reconnaître que la situation actuelle sur le plan de la santé des Autochtones au Canada est le résultat direct des politiques des précédents gouvernements canadiens, y compris en ce qui touche les pensionnats, et de reconnaître et de mettre en application les droits des Autochtones en matière de soins de santé tels qu'ils sont prévus par le droit international et le droit constitutionnel, de même que par les traités.

2. Nous demandons au gouvernement fédéral, en consultation avec les peuples autochtones, d'établir des objectifs quantifiables pour cerner et combler les écarts dans les résultats en matière de santé entre les collectivités autochtones et les collectivités non autochtones, en plus de publier des rapports d'étape annuels et d'évaluer les tendances à long terme à cet égard. Les efforts ainsi requis doivent s'orienter autour de divers indicateurs, dont la mortalité infantile, la santé maternelle, le suicide, la santé mentale, la toxicomanie, l'espérance de vie, les taux de natalité, les problèmes de santé infantile, les maladies chroniques, la fréquence des cas de maladie et de blessure ainsi que la disponibilité de services de santé appropriés.

3. Afin de régler les conflits liés à la compétence en ce qui a trait aux Autochtones vivant à l'extérieur des réserves, nous demandons au gouvernement fédéral de reconnaître les besoins distincts en matière de santé des Métis, des Inuits et des Autochtones hors réserve, de respecter ces besoins et d'y répondre.

4. Nous demandons au gouvernement fédéral de fournir un financement à long terme pour les besoins des centres autochtones, nouveaux et de plus longue date, voués au traitement de problèmes de santé physique, mentale, émotionnelle et spirituelle avec lesquels doivent composer les Autochtones et qui découlent de leur expérience dans les pensionnats, et de veiller à accorder la priorité au financement de tels centres de traitement au Nunavut et dans les Territoires du Nord- Ouest.

5. Nous demandons aux intervenants qui sont à même d'apporter des changements au sein du système de soins de santé canadien de reconnaître la valeur des pratiques de guérison autochtones et d'utiliser ces pratiques dans le traitement de patients autochtones, en collaboration avec les aînés et les guérisseurs autochtones, lorsque ces patients en font la demande.

\section{REFERENCES}

1. Available online: http://www.trc.ca/websites/trcinstitution/index.php? $\mathrm{p}=830$

2. Truth and Reconciliation Commission of Canada. Honouring the Truth, Reconciling for the Future: Summary of the Final Report of the Truth and Reconciliation Commission of Canada. 2015. Electronic pdf document: http://www.trc.ca/websites/trcinstitution/File/2015/Honouring_the_Truth_ Reconciling_for_the_Future_July_23_2015.pdf

\section{Truth and Reconciliation Commission of Canada health-related calls to action}

1. We call upon the federal, provincial, territorial, and Aboriginal governments to acknowledge that the current state of Aboriginal health in Canada is a direct result of previous Canadian government policies, including residential schools, and to recognize and implement the health-care rights of Aboriginal people as identified in international law, constitutional law, and under the Treaties.

2. We call upon the federal government, in consultation with Aboriginal peoples, to establish measurable goals to identify and dose the gaps in health outcomes between Aboriginal and non-Aboriginal communities, and to publish annual progress reports and assess long-term trends. Such efforts would focus on indicators such as: infant mortality, maternal health, suicide, mental health, addictions, life expectancy, birth rates, infant and child health issues, chronic diseases, illness and injury incidence, and the availability of appropriate health services.

3. In order to address the jurisdictional disputes concerning Aboriginal people who do not reside on reserves, we call upon the federal government to recognize, respect, and address the distinct health needs of the Métis, Inuit, and off-reserve Aboriginal peoples.

4. We call upon the federal government to provide sustainable funding for existing and new Aboriginal healing centres to address the physical, mental, emotional, and spiritual harms caused by residential schools, and to ensure that the funding of healing centres in Nunavut and the Northwest Territories is a priority.

5. We call upon those who can effect change within the Canadian health-care system to recognize the value of Aboriginal healing practices and use them in the treatment of Aboriginal patients in collaboration with Aboriginal healers and Elders where requested by Aboriginal patients.

6. We call upon all levels of government to:

- Increase the number of Aboriginal professionals working in the health-care field.

- Ensure the retention of Aboriginal health-care providers in Aboriginal communities.

- Provide cultural competency training for all healthcare professionals.

7. We call upon medical and nursing schools in Canada to require all students to take a course dealing with Aboriginal health issues, including the history and legacy of residential schools, the United Nations Declaration on 
6. Nous demandons à tous les ordres de gouvernement :

- de voir à l'accroissement du nombre de professionnels autochtones travaillant dans le domaine des soins de santé;

- de veiller au maintien en poste des Autochtones qui fournissent des soins de santé dans les collectivités autochtones;

- d'offrir une formation en matière de compétences culturelles à tous les professionnels de la santé.

7. Nous demandons aux écoles de médecine et aux écoles de sciences infirmières du Canada d'exiger que tous leurs étudiants suivent un cours portant sur les questions liées à la santé qui touchent les Autochtones, y compris en ce qui a trait à l'histoire et aux séquelles des pensionnats, à la Déclaration des Nations Unies sur les droits des peuples autochtones, aux traités et aux droits des Autochtones de même qu'aux enseignements et aux pratiques autochtones. À cet égard, il faudra, plus particulièrement, offrir une formation axée sur les compétences pour ce qui est de l'aptitude interculturelle, du règlement de différends, des droits de la personne et de la lutte contre le racisme. the Rights of Indigenous Peoples, Treaties and Aboriginal rights, and lndigenous teachings and practices. This will require skills-based training in intercultural competency, conflict resolution, human rights, and anti-racism. 